\title{
RURAL HOUSEHOLD FOOD SECURITY IN KUDUS CENTRAL JAVA
}

\author{
Iin Endya Hannavi, Minar Ferichani, Ernoiz Antriyandarti, and Susi Wuri Ani \\ Faculty of Agriculture, Universitas Sebelas Maret Surakarta, Indonesia \\ Email Corresponding Author:endyahannavi@student.uns.ac.id
}

\begin{abstract}
Evidence of previous studies indicated that food security is a common problem in most areas of the world. This study aims to determine the proportion of food consumption expenditure on total of rural household expenditure, rural household food security conditions, and factors influencing food security of rural households in Kudus District. To estimate the factors influencing food security, a series of models is created. Pooled least square regression is used to estimate the factors. This study indicate that the average proportion of food expenditure on total household expenditure is $56.4 \%$. Food vulnerability is the highest category of food security conditions of rural household in Kudus District which reached an average level of energy consumption is $113,42 \%$ with food expenditure proportion equal to $73,15 \%$. Based on analysis there are eight factors from ten factors used by researchers have influenced household food security in terms of energy consumption, while there are seven factors that affecting food security seen from household protein consumption. The analysis of the factors influencing food security in rural household in Kudus District shows that side jobs have two contradictory impacts reviewed from energy and protein consumption. This research also finds out that eggs real price does not have any influence toward rural household food security in Kudus District.
\end{abstract}

Keywords Proportion of expenditure, Energy and protein consumption, Rural household, Food security

\section{INTRODUCTION}

Food security is a condition of sufficient food from the national level up to individual level that is reflected in the availability of adequate food of both quantity and quality, safe, diverse, nutritious, equitable, affordable and not contrary to the religion and culture of the community so that people can live healthily, actively and productively in a sustainable way (Vuong, et. al. 2015). Food security is divided into four levels, i.e. national food security, regional security, household or family food security, and individual food security. The proportion of food expenditure and energy consumption are important indicators in determining household food security. Having a good national food security condition does not guarantee resilience at the regional level, even households or individual level. This is because each household has different food availability and food accents which will influence the nutritional value that can be absorbed by each individual in each family. Three pillars under-pinning food security i.e. food availability, food accessibility, and food utilization. Food availability means nutrition status (Gani, A. and Biman, C. P., 2007, World Bank, 2001, and Khan, et. al, 2012).

. Food insecurity is increasing in the world where 925 million people are undernourished. Among of those people, about 900 million people are living in 
developing countries (FAO, 2010). More than $70 \%$ of these people live in rural areas and depend, directly or indirectly, on agriculture for their living (Bashir, M.K., Steven, S., and Ram, P., 2012). Rural areas are characterized by typical living conditions, life styles, and cultural patterns (Perpar, A., 2006). The people living in urban areas have significantly different characteristics than those in rural areas.

Food has an important role in achieving food security. On the other hand, the rise in food prices causes inflation in an area. Kudus District is one of the top six areas with high inflation rate in Central Java. In 2017, the rate of inflation in Kudus District has reached $4.17 \%$ where the main factor contributing to inflation is the food sector. Majority of people in Kudus District live in rural areas. Some rural communities have livelihood as breeders and farmers (Wisadirana, 2004). Income is one important factor influencing the pattern of household consumption. The higher revenues indicate increased purchasing power and increased accessibility to good quality food. This is in line with Bennet's law stated that "the share of carbohydrate food expenditure will decrease and the price per unit of calories will increase if household incomes increase (Simatupang, P., 1997). Other factors influencing household consumption patterns are the availability and good distribution of different types of food, good knowledge of nutrition and health issues, and the level of economic growth in the region.

Level of consumption is one of the indicators to see the achievement of food security. Widyakarya Nasional Pangan dan Gizi VIII (Widyakarya National Food and Nutrition VIII) (WNPG) in 2004 suggested that the consumption of energy and protein of Indonesia population is 2.000 $\mathrm{kcal} / \mathrm{capita} /$ day and 52 gram/capita/day. (WNPG) is a forum that held periodically every four years focused on issues of science and technology development and related solutions of food and nutrition. WNPG was organized by Lembaga Ilmu Pengetahuan Indonesia (Indonesian Institute of Sciences) (LIPI) since 1968. In order to know the energy and protein consumption of Kudus District population, it can be seen from agroecological characteristics which are divided into 2 regions namely, agricultural area and industrial area. 
Table 1: Levels of Energy and Protein Consumption According to Agro-ecological Characteristics

\begin{tabular}{lcr}
\hline \multicolumn{1}{c}{ Agro-ecological Characteristics } & $\begin{array}{c}\text { Energy Consumption } \\
\text { (kcal/capita/day) }\end{array}$ & $\begin{array}{c}\text { Protein Consumption } \\
\text { (gram/capita/day) }\end{array}$ \\
\hline Agricultural areas & $1.940,9$ & 58,2 \\
Industrial areas & $1.768,9$ & 48,1 \\
Average & $1.854,9$ & 52,6 \\
\hline
\end{tabular}

Source: Dinas Ketahanan Pangan Kabupaten Kudus (Food Security Department of Kudus District), 2017

Energy and protein consumption of agricultural areas are higher than in industrial areas. This is due to the agricultural area of Kudus District has a better diversity of food consumption than the industrial area. Based on the level of energy consumption, the average value is still lower than the value of the energy adequacy standard set by WNPG VIII 2004. Whereas in term of protein consumption, the people of Kudus District has reached the established standard i.e. 52 gram/capita/ day. The main purpose of this study is to analyse the determinants of food security at the district level, especially rural households in Kudus District.

\section{MATERIALS AND METHODS}

\section{Research design and sample}

Multistage sampling technique was used to select respondents for this study. Kudus District has 9 sub-district and 123 villages so the respondent was selected using judgement sampling approach, households which is living in rural areas with certain characteristics were chosen to be respondents. this gave a total of 50 respondents, who were used as sample size for the study.

\section{Method of data collection}

Primary data and secondary data was used to collect data for the study through the use of structural interview schedule which was administered to equal number of household (50) out of which all of the respondents were used for the study. Data were collected over period of one month by the authors and variables such as qualitative and quantitative data pertaining to the social, demographic and economic aspects of the district were gathered. This research also explores information about age of household head, sex of household head, the number of family member, education level of household head, household assets, side jobs, remittance, total income, food expenditure, real price of rice and eggs.

\section{Statistical analysis:}

The proportion of food expenditure toward total expenditure is the comparison or ratio of the expenditure amount for household food to the household expenditure. 
$\mathrm{PF}=\frac{P p}{T P} \mathrm{x}$

$100 \%$

Legends:

$\mathrm{PF}=$ Food expenditure proportion $(\%)$

$\mathrm{Pp}=$ Food expenditure (rupiah)

$\mathrm{TP}=$ Total rural household expenditure (rupiah)

In order to determine the value of

household food security, some experts use different indicators. One of the indicators is energy consumption cribssclassified with food expenditure. There are four food security criteria which are food secure, vulnerable, questionable, and food insecure (Maxwell, et al., 2000).

Table 2: Food Security Measurement: Food Expenditure Segment and Energy Consumption

\begin{tabular}{lll}
\hline \multirow{2}{*}{ Household Energy Consumption } & \multicolumn{2}{c}{ Expenditure Segment } \\
\cline { 2 - 3 } & $\begin{array}{l}\text { Low }(<60 \% \text { total } \\
\text { expenditure })\end{array}$ & $\begin{array}{l}\text { High }(\geq 60 \% \text { total } \\
\text { expenditure })\end{array}$ \\
\hline Adequate $(>80 \%$ kecukupan energi) & 1. Secure & $\begin{array}{l}\text { 2. Vulnerable } \\
\text { Lack }(\leq 80 \% \text { kecukupan energi) }\end{array}$ \\
\hline
\end{tabular}

Adopted from Maxwell, et. al. (2000)

Pooled Least Square analysis method is applied to analyse the data. The factors influencing rural household food security are age of household head, sex of household head, the number of family member, education level of household head, household asset, side jobs, remittance, income, food expenditure, rice real price, and eggs real price. Energy consumption and protein consumption are used as the dependant variable. Here is the equation that can be formulated from those factors:

$Y_{1,2}=\alpha+\beta_{1} X_{1}+\beta_{2} D_{1}+\beta_{3} X_{2}+\beta_{4} X_{3}+$ $\beta_{5} \mathrm{X}_{4}+\beta_{6} \mathrm{D}_{2}+\beta_{7} \mathrm{X}_{5}+\beta_{8} \mathrm{D}_{3}+\beta_{9} \mathrm{X}_{6}+$ $\beta_{10} X_{7}+$ e ....

Legends:

$\mathrm{Y}_{1}=$ Total household energy consumption (kcal)

$\mathrm{Y}_{2}=$ Total household protein consumption (gram)

$\alpha=$ Interception

$\beta_{1-} \beta_{10}=$ Coefficient

$\mathrm{X}_{1} \quad=$ Age of household head (years)

$\mathrm{D}_{1} \quad=$ Sex of household head

Dummy, 1 = Male
$0=$ Female

$\mathrm{X}_{2} \quad=$ The number of family member

$\mathrm{X}_{3}=$ Education level of household head

$\mathrm{X}_{4} \quad=$ Household asset (rupiah)

$\mathrm{D}_{2} \quad=$ Side jobs

Dummy, $1=$ Yes $0=$ Not

$\mathrm{X}_{5} \quad=$ Remittance (rupiah)

$\mathrm{D}_{3} \quad=$ Income (rupiah)

Dummy, 1 = High Income $0=$ Low Income

$\mathrm{X}_{6} \quad=$ Food expenditure (rupiah)

$\mathrm{X}_{7} \quad=$ Rice real price (rupiah)

$\mathrm{X}_{7} \quad=$ Egg real price (rupiah)

e $\quad=$ Error

\section{RESULT AND DISCUSSION}

Characteristics of rural households in this study included the age of household head, education lev(di) of household head and the number of family members. In this study the sample amounted to 50 households, residing in the rural Kudus District. The characteristics of households samples in rural areas can be seen in Table 3 . 
Table 3: Characteristics of rural household sample in Kudus District

\begin{tabular}{lr}
\hline \multicolumn{1}{c}{ Variable } & Average and Description \\
\hline Age of household head & $\begin{array}{r}47.22 \\
\text { (included in the productive age category) }\end{array}$ \\
\hline Level education of household head & 8 \\
(elementary school category)
\end{tabular}

Source: Household Survey, 2017

Figure 1 presented data of food expenditure, non-food expenditure and total monthly expenditure of rural households samples in Kudus District.

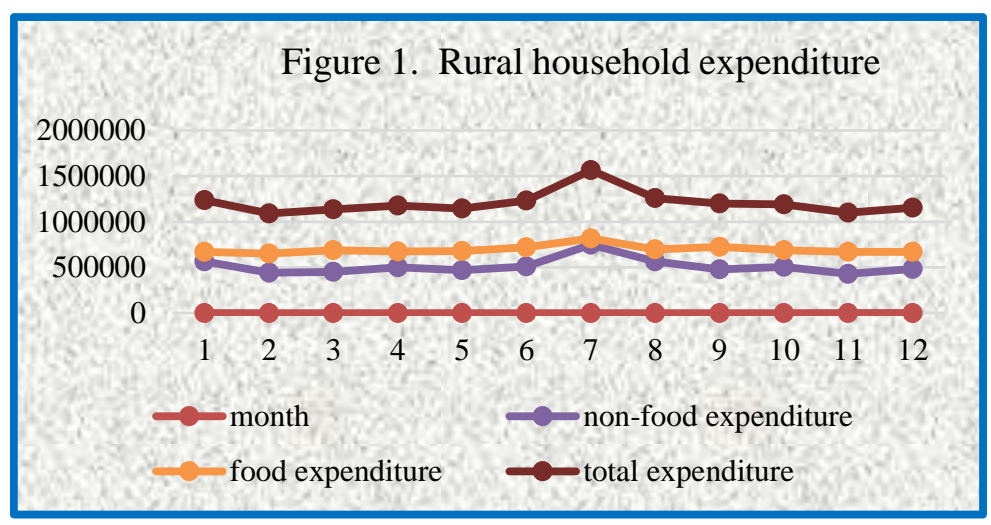

Source: Household Survey, 2017

Table 4 shows the analysis result they are, age of household head and of the factors influencing food security reviewed from the energy and protein consumption. Based on the analysis education level. Meanwhile, if it is reviewed from the protein consumption, result, it is found that from the 10 factors it is shown that from those 10 factors used by the researcher, there are two used by the researcher, there are 3 factors factors that do not influence the rural not influencing the rural household food security in Kudus District they are side household food security in Kudus District job, remittance, and eggs real price.

Table 4: Estimation result of energy consumption in Kudus district

\begin{tabular}{|c|c|c|c|c|}
\hline \multirow[b]{2}{*}{ Variable } & \multicolumn{2}{|c|}{ Energy } & \multicolumn{2}{|c|}{ Protein } \\
\hline & Coefficient & Standard Error & Coefficient & $\begin{array}{c}\text { Standard } \\
\text { Ereor }\end{array}$ \\
\hline Age of household head & 6.75463 & 4.155531 & $-0.3202684^{*}$ & 0.1791319 \\
\hline Sex of household head & $992.8697 * * *$ & 125.6275 & $25.10071 * * *$ & 3.748099 \\
\hline The number of family member & $590.9588 * * *$ & 32.92007 & $13.60465 * * *$ & 1.050081 \\
\hline Level education of household head & 65.84435 & 42.35382 & $7.584265^{*}$ & 4.231206 \\
\hline Household asset & $3.14 \mathrm{e}-07 * *$ & $1.26 \mathrm{e}-07$ & $2.22 \mathrm{e}-08 * * *$ & $2.74 \mathrm{e}-09$ \\
\hline Side job & $-512.3612 * * *$ & 112.8351 & 4.448538 & 3.516202 \\
\hline Remittance & $0.0003913 *$ & 0.0002274 & $9.97 \mathrm{e}-06$ & $7.04 \mathrm{e}-06$ \\
\hline Income & $-295.8088 * * *$ & 108.4611 & $23.92512 * * *$ & 3.64529 \\
\hline Food expenditure & $0.0012377 * * *$ & 0.0001321 & $0.0000849 * * *$ & $4.17 \mathrm{e}-06$ \\
\hline Rice real price / eggs real price & $-0.2930936 * * *$ & 0.1130179 & 0.0201425 & 0.1255266 \\
\hline Constanta & 4519.579 & 757.889 & 48.73264 & 18.5389 \\
\hline Number of Observation & 600 & & 600 & \\
\hline F-value & $78.27 * * *$ & & $93.37 * * *$ & \\
\hline $\mathrm{R}^{2}$ & 0.5706 & & 0.6132 & \\
\hline
\end{tabular}


Total expenditure is classified into two which are food expenditure and non-food expenditure (Verma, 2011). The amount of average total expenditure in this research is 1,251,027.891 rupiahs. Based on the research result, it can be seen that the food expenditure is $706,507.058$ rupiahs or parallel to $56.4 \%$ from the total expenditure and for the non-food expenditure is $544,520.833$ or $43.6 \%$. It can be concluded that the proportion for food expenditure is higher that the proportion for the non-food expenditure, where the food expenditure takes more portion of the household expenditure, it means that the respondent's household prioritizes to fulfil their household food needs. This issue shows that the welfare and fulfilment of the household food consumption needs are still low. The higher the food expenditure proportion, the lower the fulfilment level of household food consumption need level will be (Kartika, 2005 and Sekhampu, 2012)

Food security covers 3 aspects which are availability, consumption, and distribution. Availability can be interpreted as the food availability which is enough for all the people whether it is seen from the quantity, quality, safety, and affordability. Consumption means there is an ability for each household to access sufficient food for each of its members so that they can live healthily. Distribution deals with the food availability for each people's class. In this research, food security is seen from the indicators of food expenditure proportion and energy also protein consumption spread compared to the suggested consumption based on the age and sex.

The secure category distribution of level energy adequacy has reached $107.94 \%$ with the food expenditure proportion is $47.88 \%$; the vulnerable one of level energy adequacy has reached $113.42 \%$ with the food expenditure proportion is $73.15 \%$; the questionable one of level energy adequacy has reached $69.43 \%$ with the food expenditure proportion of $46.51 \%$; while the insecure one has an average of $69.62 \%$ with the food expenditure proportion of $79.77 \%$. The distribution is almost even because the respondents chosen have various job, so that it will influence the average income and the food stuffs bought by the respondents' household.

The variable of household head's age is significantly negative to the protein consumption, while it is not significant to the energy consumption. The age of household head variable has significant negative influence towards work productivity level, meaning that the 
higher one's age the lower his/her work productivity will be. As one's age increases it will lower one's creativity and usability (Pandapotan, 2013). Sex of household head influences rural household food security positively reviewed from the energy or protein consumption aspect. The result of the research shows 24\% respondent households have female as the head of household and $76 \%$ have male as the head of the household. Sex influences household food security positively, households having male as the head will tend to be food secure compared to those of female (Abdullah, at. al., 2017; FelkerKantor and Wood, 2012; Zakari, at. al. 2014)..

Positive influences are shown by the number of family member variable towards rural household food security in Kudus District. The number of family member allows the number of family member working, so that it may raise food security (Olayemi, 2012). The research result shows that most family members are in productive age so that their existence can help to increase the household's income and security. The number of family member is the main determiner of food security (Amaza, et al. 2006). In this research, it is found that most family members are in productive age, so that their existence can increase family's income which will influence food quality and quantity consumed by that household. Reviewed from the protein consumption aspect, the household head's education level positively influences the food security. The effect of education towards food security are based on the rural population, human capital theory states that human capital is the main determiner of production and then the success chance of work and income (Mutisya, et al., 2016). These theories prove that education as proxy of human capital, are related to productivity and efficiency. The level of education will have implications in the food quality that can be seen from its nutrition level, so that food diversity and nutrition adequacy of that household can be fulfilled.

Significant value differences are indicated from household asset variable reviewed from energy consumption or protein consumption and they both have positive influences on rural household food security in Kudus District. The lower the productive asset possession is, the higher food insecurity will it have, the productive asset possession tends to be directed on the household income level, if the income is low, the purchasing power will be low too (Sari and Bambang, 2009). Household assets that can generate 
income will raise the probability for food security of rural household in Kudus District. Side job variable influences negatively toward rural household food security reviewed from energy consumption. Having many jobs, inflexible working hour, and overnight work will influence the time limitation to choose and prepare healthy food (Devine, et. al., 2003). Thus, even if rural household income increases the increase in rural household food security of Kudus District is not guaranteed. Different results shown by the analysis result factors influencing rural household food security in Kudus District reviewed from protein consumption. The energy supply will be needed even more by the body compared to protein. Energy will help body to do a series of activities done in side jobs. One of the important nutrition aspects for workers is worker's energy supply. Energy supply inappropriate with the energy need of a worker will make that worker get tired faster (Tasmi, et al., 2015).

Remittance becomes an important thing in income source and external finance for many people in developing countries and economic sources that promises a development (Jebran, et al., 2016). In this research there are some family members who wander from their hometown, then send some of their salary for the remaining members who stay at home. Remittance variable positively influences rural household food security in Kudus District. Households receiving remittance money will reach food security, while those not receiving remittance money will experience a lack in food security (Abdullah, et. al., 2017).

Different influences shown by total income variable reviewed from the energy consumption has negative influence while reviewed from protein consumption it has positive influence. Reviewed from energy consumption the consistent analysis result with Engel Law stating that the higher one's income the lower the proportion for food expenditure. In the other hand, reviewed from protein consumption explaining that income factor is one of the important factors in deciding household consumption pattern (Sinaga, et., al., 2013). Higher income shows a higher purchasing power as well as the accessibility toward a better food quality. In this research the average of total household income is higher than the minimum regional salary settled. Household that having high income will try to fulfil quality demand, so that rice consumption will be lowered and will move on expensive foods like meat or fast food (Purwantini, and Ariani, 2006). 
Food expenditure segment is suitable for food security indicator because it has a strong relationship with various food security measurement which is consumption level and food diversity (Ilham, and Bonar, 2007). According to that reference, food expenditure variable is put into analysis model. Reviewed from energy and protein consumption, it has positive influence toward rural household food security of Kudus District. Food expenditure segment will show food diversity existing in a household, the more various the food consumed in a household, the higher the food security in that household will be.

Real rice price variable influences rural household food security in Kudus District negatively. The increase in rice price will impact on the rice availability to fulfil customers' need. Food fulfilment with enough availability condition is an important aspect to form a good food security for a household (Santi, and Andrias, 2005). The major main food of Kudus people is rice, so that rice availability in the market will influence the food security of rural households. Real eggs price variable does not have any influence toward rural household food security in Kudus District reviewed from protein consumption. Eggs are the type of food without close substitution, so that its price change will relatively not influence its demand. It happens because the customers will still buy eggs or in other words the demand of eggs is inelastic (Mankiw, and Taylor, 2006). Besides that, the average total income of rural households is higher than regional minimum salary (UMR) settled in Kudus District, so that if there is an increase of eggs price, the demand of it in the market will not decrease significantly.

\section{CONCLUSION}

The analysis of the factors influencing food security in rural household in Kudus District shows that side jobs have two contradictory impacts reviewed from energy and protein consumption. Someone having many jobs, inflexible working hours, and overtime work will influence the time limitation to choose and prepare healthy food. Thus, even though the rural household income increases, the increase in food security will not be guaranteed. The energy supply will be needed compared to protein. Energy will help our body to do a series of activities done in side jobs. This research also finds out that eggs real price does not have any influence toward rural household food security in Kudus District. Eggs are the type of food without close substitution, so that its price change will relatively not influence its demand. It happens because the customers will still buy eggs or in other words the demand of eggs is inelastic. 


\section{REFERENCES}

Abdullah, S., Zhou, D., Shah, T., Ali, S., Ahmad, W., Bahar, I. Ud. Din., Ilyas, A. (2017), "Factors Affecting Household Food Security in Rural Northern Hinterland od Pakistan", Journal of the Saudi Society of Agricultural Sciences, S1658077X(16)30170-9,

http://dx.doi.org/10.1016/j.jssas.201

7.05.003. [Accessed 7 March 2018]

Amaza, P.S., Umeh, Joseph Chinedu, Helsen, J., Adejobi, A.O. (2006), "Determinants and Measurement of Food Insecurity in Nigeria: Some Empirical Policy Guide", Annual Meeting, August 12-18, 2006, Queensland, Australia 25357, International Association of Agricultural Economists. https://ageconsearch.umn.edu/recor $\mathrm{d} / 25357$

Bashir, M.K., Steven, S., and Ram, P. (2012), "The Determinants of Rural Household Food Security for Landless Households of the Punjab, Pakistan", Working Paper 1208, School of Agricultural and Resource Economics. http://www.are.uwa.edu.au

[Accessed 7 March 2018]

Devine C.M., Connors M.M., Sobal J. and Bisogni C.A. (2003), "Sandwiching it in: Spillover of Work onto Food Choices and Family Roles in Lowand Moderate-Income Urban Households", Social Science and Medicine, Vol 56 No.3, pp: 617630.

FAO. (2010), "The State of Food Insecurity in the World", Addressing Food Insecurity in Protracted Crises, Rome, 2010, ISBN 978-92-5106610-2.
Felker-Kantor, E; Wood, C.H. (2012), "Female-Headed Households and Food Insecurity in Brazil", Food Secur. 2012, Vol. 4, pp: 607-617.

Gani, A. and Biman, C. P. (2007), "Food Security and Human Development", International Journal of Social Economics, Vol. 34 No. 5, pp: 310-319. Emerald Group Publishing Limited, https://doi.org/10.1108/030682907 10741570.

Ilham, N. and Bonar. (2007), "Penggunaan Pangsa Pengeluaran Pangan Sebagai Indikator Komposit Ketahanan Pangan (Food Expenditure Used to Food Security Composite Indicator", Soca (SocioEconomic of Agriculture and Agribusiness), Vol. 7 No. 3, pp: 122 ISSN 1411-7177 3 November 2007 ,

https://ojs.unud.ac.id/index.php/soc a /article/view/4217. (In Bahasa Indonesia).

Jebran, K., Abdullah, Iqbal, A. and Ullah, I. (2016), "Effects of Remittances on per Capita Economic Growth of Pakistan", Pakistan Business, Vol. 18 No. 1, pp: 1-18.

Kartika T.W.W. (2005), “Analisis coping strategy dan ketahanan pangan rumahtangga petani di desa Majasih kecamatan Sliyeg kabupaten Indramayu (Analysis of Coping Strategy and Household Food Security of Farmers in Majasih village, Sub-district Sliyeg, Indramayu district", Departemen Gizi Masyarakat dan Sumberdaya Keluarga Fakultas Pertanian Institut Pertanian Bogor. (In Bahasa Indonesia).

Khan, R. E. A., Azid, T. and Toseef, M. U. (2012), "Determinants of Food 
Security in Rural Areas of Pakistan", International Journal of Social Economic. Vol. 39 Issue: 12, pp: 951-964, Emerald Group Publishing Limited, https:// doi.org/10.1108/030682912112690 82.

Mankiw, N. G. and Taylor, M. P. (2006), "Microeconomics", United Kingdom: Thomson Learning.

Maxwell D., C. Levin, M. A. Klemeseau, M. Rull., S. Morris and C. Alandeke. (2000), "Urban Livelihoods and Food Nutrition Security in Greater Accra, Ghana", IFPRI in Collaborative with Noguchi Memorial for Medical Research and World Health Organization, Research Report No. 112, Washington, D.C (US).

Mutisya, M., Moses, W. N., Caroline W. K., and Ngianga-bakwin K. (2016), "The Effect of Education on Household Food Security in Two Informal Urban Settlements in Kenya: a Longitudinal Analysis", Food Security Journal, Vol. 8 No. 4 pp: 743-756, August 2016. [Accessed 7 March 2018]

Olayemi, A. O. (2012): "Effects of Family Size on Household Food Security in Osun State, Nigeria", Asian Journal of Agriculture and Rural Development, Vol. 2, No. 2, pp: 136-141.

Pandapotan, E. T. (2013), "Pengaruh Variabel Pendidikan, upah, masa kerja dan usia terhadap produktivitas karyawan (studi kasus pada PT. Gandum Malang) (Influence of Variable Education, Wage, Employee and Age of Employee to Employee Productivity (Sase Study at PT. Gandum Malang))", Jurnal Ilmi
Ekonomi, Vol. 1 No. 2 pp: 88-97. E-jurnal: Malang. (In Bahasa Indoensia).

Perpar, A. (2006), "Characteristics of Rural Areas in Slovenia: Advantages, Weaknesses and Possibilities for Improvement of Present Situation from Viewpoint of Sustainable Rural Development", Journal Central European Agriculture, Vol. 8 No. 2, pp: 229-265.

Purwantini, T. B. and Ariani, M. (2006), "Analisis Konsumsi Pangan Rumah Tangga Pasca Krisis Ekonomi di Provinsi Jawa Barat (Analysis of Consumption of Household Food Post Economic Crisis in West Java Province)", Jurnal Sosial-Ekonomi Pertanian dan Agribisnis, Vol. 6 No. 1 pp: 1$16 \quad$ ISSN $1411-7177$ https://ojs.unud.ac.id/index.php/soc a/article/view/4117. (In Bahasa Indonesia).

Santi, S. and Andrias, D. R. (2005), "Hubungan Ketersediaan Pangan dan Keteraturan Penerimaan Raskin dengan Status Ketahanan Pangan Rumah Tangga Penerima Raskin (Food Availability and Regularity Acceptance of Rice Support with Resilient Household Food Security Status)", Vol. 10 No. 2 pp: 1-15, http://dx.doi.org/10.20473/mgi.v10i 2.97-103. (In Bahasa Indonesia).

Sari, M. R. and Bambang, P. (2009), "Faktor-Faktor yang Mempengaruhi Kerawanan Pangan Rumah Tangga Miskin di Desa Wiru Kecamatan Bringin Kabupaten Semarang (Factors Affecting Poor Household Food Insecurity in Wiru Village, Subdistrict of Bringin, Semarang District)", JEJAK. Vol. 2. No. 2 pp: 
135-143 September 2009. (In Bahasa Indonesia).

Sekhampu, T. J. (2012), "Socio-Economic Determinants of Household Food Expenditure in a Low Income Township in South Africa", Mediterranean Journal of Social Sciences, Vol. 3 No. 3 pp: 449-453 September 2012. Doi: 10.5901/mjss.2012.v3n3p449.

Simatupang, P. (1997), “Toward Sustainable Food Security: The Need for a New Paradigm", Vol. 99 from Working Paper, CIES, Universiry of Adelaide: ACIAR Indonesia Research Project.

Sinaga, R. J., Lubis, S. N., and Darus, M. B. (2013), "Kajian Faktor-Faktor Sosial Ekonomi Masyarakat Terhadap Ketahanan Pangan Rumah Tangga Di Medan (The Determinant of Social Economy of Community toward Household Food Security in Medan)", Journal On Social Economic of Agriculture and Agribusiness, Vol. 2 No. 5 pp: 1-13.

https://jurnal.usu.ac.id/index.php/ce ress/article/view/7876 (In Bahasa Indonesia).

Tasmi, D., Halinda, S. L., and Eka, L. M. (2015), "Hubungan Status Gizi dan Asupan Energi dengan Kelelahan Kerja pada Pekerja di PT. Perkebunan Nusantara I Pabrik Kelapa Sawit Pulau Tiga Tahun 2015 (Relationship Between Nutrition Status and Energy Intake with Work Fatigue on Workers at PT. Perkebunan Nusantara I Pabrik Kelapa Sawit of Pulau Tiga in 2015)", Jurnal Lingkungan dan Kesehatan Kerja, Vol. 4 No. 2 pp: 1-7. (In Bahasa Indonesia). https://jurnal.usu.ac.id/index.php/lk k/article/view/11297/5777

[Accessed 7 March 2018]
Verma, M., Hertel, W. T., and Preckel, P. V. (2011), "Predicting within country household food expenditure variation using international crosssection estimates", Economics Letters, Elsevier, Vol. 133 No. 3 pp: 218-220. doi: https://doi.org/10.1016/j.econlet.20 $\underline{11.07 .004 .}$.

Vuong, T. N., Gallegos, D., and Ramsey, R. (2015), "Household food insecurity, diet, and weight status in a disadvantaged district of $\mathrm{Ho}$ Chi Minh City, Vietnam: a crosssectional study, BMC Public Health, Vol. 15 No. 232, doi: 10.1188/s12889-015-1566-z.

World Bank. (2001), "The World Bank Annual Report 2001: Year in Review (English)", Washington, DC: World Bank. http://documents.worldbank.org/cur ated/en/ 624991468764410016/Year-inreview. [Accessed 19 February 2018].

Zakari, S., Liu Y., and Baohui, S. (2014), "Factors Influencing Household Food Security in West Africa: The Case of Southern Niger), Sustainability, Vol 6, No. 3 pp: 1191-1202. https://doi.org/10.3390/su6031191 [Accessed 7 March 2018] 